\title{
TOM WHITE-1929-1984-REFLECTIONS
}

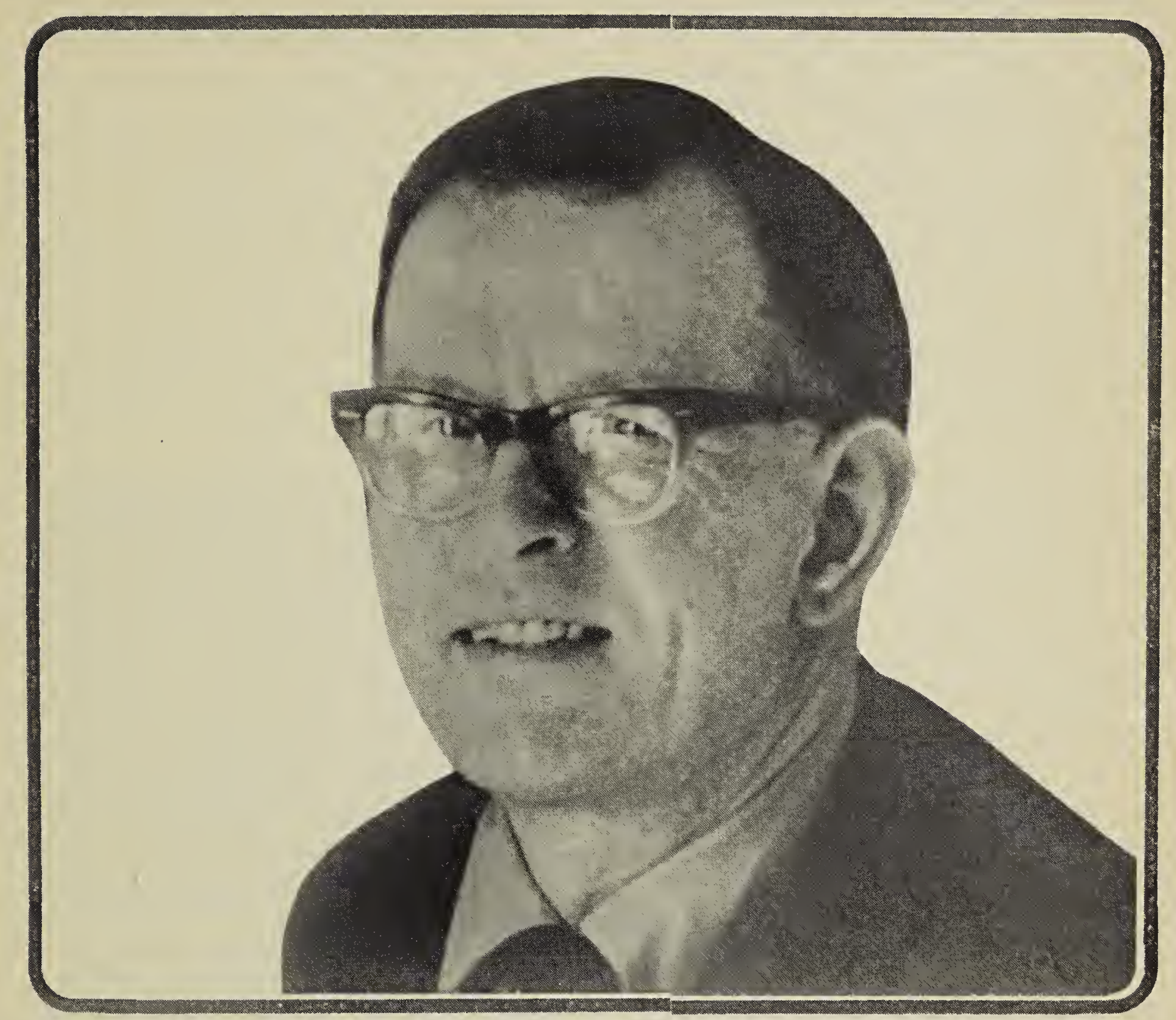

"We need the tonic of wildness. At the same time that we are earnest to explore and learn all things, we require that all things be mysterious and unexplorable. We need to witness our own limits transgressed and some life pasturing freely where we never wander." - Henry David Thoreau, Walden

Tom White needed the tonic of wildness; it took the compelling qualities of the Canadian frontier to forge the full realization of his potential. Certainly this was not unique with Tom - many other Europeans, including Grey Owl, have been captivated by that same spirit and fascination that characterize vast areas of the North American wilderness. In particular however, it was the Saskatchewan landscape which fanned for Tom what had been no more than a cursory interest in natural history in his native Britain. It forever changed his life; it permeated all he did.

Tom lived in Saskatchewan for 25 years. In that time he criss-crossed the province in the pursuit of his interests. While he occasionally travelled beyond its borders, it was Saskatchewan that fascinated him, to him it was sufficient and consuming. He 
walked its sand-dunes and eskers, its hills and coulees, grasslands and forests. He did not simply keep pace with his companions, but marched to a "different drummer," and followed that beat wherever it led. He was a voracious reader, with an active, restless mind. His zeal and enthusiasm drew people to his projects and to him - he offered stimulation, adventure and leadership. The challenge of Saskatchewan brought immeasurable richness to the life of Tom White; in turn, when he left it, he had enriched the lives of us all through his contributions in natural history, poetry, conservation, heritage preservation and architecture. And, for many of us, he left wonderful memories.

Bird-watching held little interest for Tom. In his typically analytical way, he often pondered on just what it could be about birds that attracted so many people; his conclusion - their colors. What did captivate him was the mysterious, the wild, the inscrutable, and it was the Cougar that ignited a latent spark in Tom. His fascination with its presence in Saskatchewan (and later, also that of the grizzly) became a passion. For him it was a rare and beautiful symbol of wild nature, and for over a decade he spread a net over the province, pursuing relentlessly every trace of a report of Cougar or Cougar sign - hundreds in all. He became expert on their habits, their tracks, on the difference among wolf, Cougar and lynx tracks. The result of this research was published in book form in 1982 (Saskatchewan Cougar - elusive cat). Some of the reports are quoted verbatim, and not only offer insight into the nature of this animal, but also paint colorful sketches of prairie people and their environments:

"I'm interested in painting wild mushrooms and about three blocks from our home on the river bank I noticed a face of the biggest, pudgiest pussy cat and immediately ran after it. It scurried up a big poplar and snarled back - it was no house cat or lynx. It was tan, huge paws and the long tail could only divulge it as a cougar. Nobody believes me. I did not report this to anyone except a few birdwatchers, for the simple reason that there would have been a posse after this young, regal animal - and I hate people destroying animals." (Saskatchewan Cougar - elusive cat, p. 67).

The search for the Cougar led him to the vast and inaccessible Pasquia Hills, and eventually to the hypothesis that besides Cougar, there might possibly still be remnants of the Great Plains Grizzly in this rugged forest. Henry Kelsey had sighted grizzly in the area in 1690, and Tom had heard recent Cree stories of "big bear up in the Hills." Thus the Pasquias gradually became the chief focus for his research, and increasingly exercised their magnetism upon him. They epitomized the wilderness, and again and again he returned, not just for Cougar and grizzly, but to explore the Hills themselves.

The problem of establishing conclusively a current presence of the grizzly in Saskatchewan proved a much more difficult task than for the Cougar. Tom's search, however, did turn up evidence, old and new, of huge bears, and this evidence, including photos and claws, was shared with recognized bear experts in both the United States and Canada. The giant Veillardville bear, shot in the Pasquias in 1939 was "almost certainly a grizzly" according to Dr. Phillip Youngman, Curator of Mammals in the National Museum in Ottawa. Frank Craighead, an Idaho expert, in personal correspondence with Tom in 1971, stated that pictures of both a bear killed in 1954 and the Veillardville bear "look like grizzlies." Tom gradually became convinced the only definitive proof of grizzly bear in Saskatchewan would be the securing of a skull. This led to repeated digs to try to recover the skull of the buried Veillardville bear. Tom's investigations and conclusions on the grizzly have been recorded in an unpublished manuscript entitled "The grizzlies of Saskatchewan." 
It was during his research that Tom organized his famous Pasquia Hills expeditions of the $1960^{\prime}$ s and early $1970^{\prime}$ s, pushing for the heart of the Hills from every direction - up the Rice River and Bainbridge Canyons on the north, from the Fir River and Greenbush Trail on the south, the Man River on the west, the Pasquia and Chemong rivers on the east. No one who accompanied him on these hard-driving treks will ever forget them - back-packing by map and compass through muskeg and black spruce, along poplar ridges and game trails, through a wilderness forest, wild and beautiful. He was not a skilled woodsman, but it was he who carried the vision, supplied the zeal - the acknowledged leader.

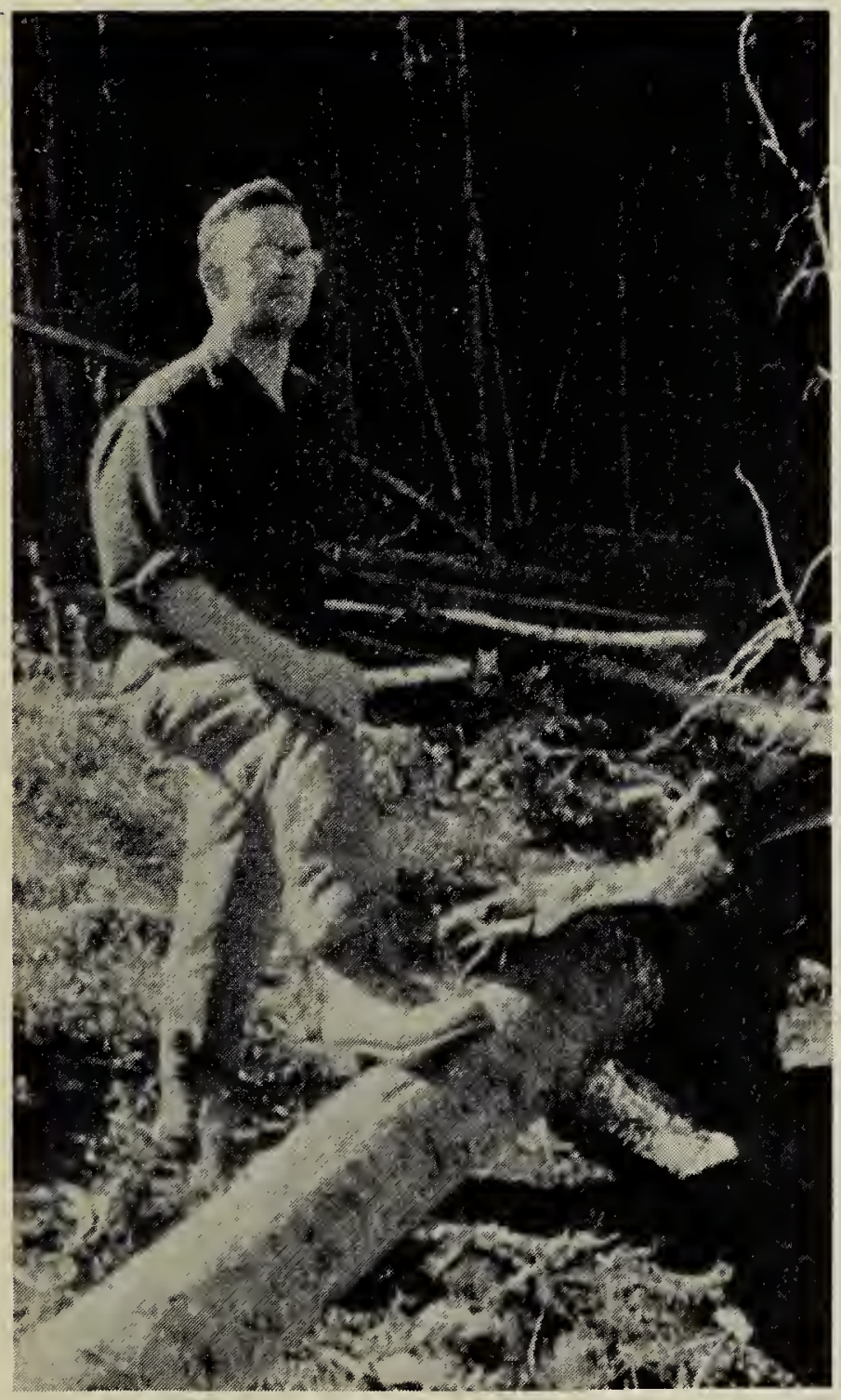

Tom White

On several occasions he reached the central summit, the most inaccessible part of the Hills - Wildcat Hill.
Tom believed fervently in the value of wilderness to man - we need the wild remote places now more than ever. Roads should not be built to all these areas, some should remain relatively inaccessible, not capable of being reached by everyone. They symbolize the "tops of the mountains," shrouded in mist. Though very few ever achieve the summit, we need to know that these wild places exist, that the shadowy Cougar still prowls the canyons, that there just may be grizzlies lurking in the forest. Thus was born Tom's idea of having the core area of the Hills preserved for all time and for all people. Through his vision the Wildcat Hill Wilderness Area was established, the first of its kind in the province. In this process he was not a loner, but worked cooperatively with all who were willing and able to help - friends, societies and government.

A lake just north of Wildcat Hill was named White Lake in honor of his efforts in preserving wilderness areas. He reached the Lake on a memorable occasion after it was named. He had packed across the Hills by map and compass, heading for the lake; dusk had arrived on the second day - still no lake. A rude camp was made, with a hole in the nearby muskeg providing water. Next morning during breakfast it came the call of a loon, directly ahead. Cheers broke the silence - that had to be the lake! After walking less than a quarter mile, Tom stood on the shore of White Lake, a moment of tremendous exhilaration. In 1974, Tom was instrumental in having the Kelsey Trail (between Nipawin and The Pas) dedicated with grizzly bear silhouettes commemorating the first white explorer to observe and describe the grizzly bear in North America.

Tom's values and aesthetic qualities were distilled and preserved in his poetry. With great imagery he captured the craft and power ofthe Cougar, the beauty and fragrance of the prairie, and man's tragic alienation from nature. His poems were published just before his death in a booklet, "Wilderness Ways." 
Tom led through action and example. His life and his values remain for us a stimulus and a challenge. He demonstrated vividly the contribution that the amateur can make in research and conservation. He has reminded us forcefully that the priceless natural heritage that is Saskatchewan is already being eroded. His involvement in natural history followed a sequential pattern, beginning with his initial personal interest, developing through his travels and research, and reaching a permanent consolidation for the benefit of future generations in his writing, his conservation efforts and his poetry. His vision and concern are evergreen; they are still leading us.

"We need an enrichment other than material prosperity, and to gain it we have only to look around at what our own country has to offer. ... We have something here that no other country has." - Grey Owl

Tom White was born in Wales and grew up in both England and Wales. In 1959, with his wife Pamela, he came to Regina to practise his profession as an architect. He was a member of both the Regina and Saskatchewan Natural History Societies, becoming president of the Regina Society in 1965, and serving as chairman of the Conservation Committee of the Saskatchewan Society in 1973.

He was the founding chairman of Heritage Regina in 1977, served on the Saskatchwan Heritage Advisory Board from 1977 to 1979 , and was Regina Branch chairman of th Community Planning Association of Canada in 1975-76. He helped restore Stanley Mission on the Churchill River, the oldest building in the province.

Tom served on the first Board of the Regina Native Friendship Centre, planned Huston Heights, a residence for the handicapped, and as a Rotary Club member, planned the shipping of tons of old Regina school textbooks to Jamaica. In 1984 he won a municipal heritage award for preserving the heritage character and economic viability of the Regina Transit Centre on 11th Avenue.

In 1984, he was awarded a life membership in the Saskatchewan Association of Architects in recognition of his contribution to the cultural heritage of the province.

Tom is survived by his wife Pamela, his son Eddie, and his daughter Wendy.

How dull it is to pause, to make an end, To rust unburnish'd, not to shine in use! - Tennyson, Ulysses

- JACK MacKENZIE, 56 Fines Drive, Regina Saskatchewan. S4N 5 K5 
By: Tom White

Cougar prowls? be silent night,

Wh th" owos that ghow with hidden light. She stalks the whinding, Ionely trails; Whare grey woth homis and tone toon wails.

Green-eyed phantom on padded paws. With reline steal th and hidden claws, Mysterious beast with tawny hide. Her muscles rippling through her side.

Silentiy through hilk and creek, While searching for orevening meat, To feed her kits and have her fill, And cull the herds as iature willed.

The tired or 014 the weak and sick, bis ased or wounded, gnawed by ticks, The injured, lame or starving deer, And those that doze and do not hear.

* The smaller game that aren't so sharp,

- Who do not 1 isten in the dark, Who do not sense a steal thy tread, When all the forest's still and dead.

Ys:

Cougar prowling in the night. With orbs that glow with hidden light. She stalks the winding lonely trails, Where grey wolf howls and lone loon wails. 